\title{
El Catecismo breve que Bartolomé Castaño nunca escribió
}

\author{
LUIS RESINES LLORENTE
}

RESUMEN: El lector encontrará grandes lagunas en la información biográfica; a la muerte de Castaño no se constata que escribiera ningún catecismo. La realidad es que empleó y acaso tradujo uno breve, que ya existía. Con el tiempo se pasó a asegurar, sin base, que él era el autor; y la repetición de este dicho durante siglos dio por cierto que era el autor de un catecismo que empleó, pero no llegó a escribir.

Palabras Clave: Castaño, catecismo breve, Sinaloa, Pedro de Gante.

ABSTRACT: The reader shall found a great lot of silences about the biographical information. When Castaño died, not are founded no catechism between his papers. He only used and perhaps translated a previous catechism. But it is repeated he was the author, that nobody doubt of it. For centuries it was printed so in many editions, but he do not write the catechism wit his name.

Key Words: Castaño, brief catechism, Sinaloa, Pedro de Gante.

Abordar qué pudo suceder con el denominado Catecismo breve, asignado a Bartolomé Castaño, jesuita, es un auténtico ejercicio de adivinación, porque no hay respuestas fáciles, comprobadas para la mayor parte de las incógnitas que suscita su estudio, y todo queda sumido en una nebulosa que convierte la seguridad en algo vaporoso, tenue, que la más mínima brisa se puede llevar. 
Con esa tremenda falta de certeza, quiero intentar poner algo de luz en el tema, o al menos despejar en lo posible las brumas que envuelven este texto.

\section{Bartolomé Castaño}

La más reciente y quizá también la más depurada reseña biográfica de Bartolomé Castaño es la que consta en el Diccionario Histórico de la Compañía de Jesús, 698-699, debida a la labor conjunta de F. Zubillaga y J. Gómez. La nota recaba informaciones anteriores, y las criba, de manera que se puede asignar a esta noticia una fiabilidad notable.

Por proceder con un poco de orden, es obligado proporcionar la noticia de la obra que le precedió, que es el origen de todas las informaciones. Se trata de la que escribió el jesuita Tomás de Escalante, y que lleva por título Breve noticia de la vida Exemplar y Dichosa Muerte del Venerable Padre Bartholomé Castaño de la Compañía de Jesvs, que dio a los Svperiores de las Casas y Colegios desta Provincia de Nuevo México el P. Francisco Ximénez, siendo Prepósito de la Cassa Professa de esta ciudad de México en carta. Dispuesta por el Padre-, de la misma Compañía. Con licencia, En México, por Iuan de Ribera, en el Pedradillo [sic],16791.

Puesto que Castaño murió en 1672, habría que atribuir a la redacción de Escalante una notable verosimilitud, ya que fue redactada a partir de la información en forma de carta del superior, Francisco Ximénez, a tan sólo siete años de su fallecimiento. Sin embargo, el estilo marcadamente apologético, de exaltación del biografiado, deja una cierta duda en lo escrito.

La reseña apuntada de Zubillaga y López, más sobria, resulta más fiable, además de que recopila información bien documentada. Dice así:

«Castaño, Bartolomé.

Misionero Padre lengua.

N[acido] c. 1601 Santarém, Portugal; m[uerto] 21 diciembre 1672,

México D. F. (México). E[ntrada en la Compañía] c. 1622, Madrid (España); o[rdenado] c. 1631, México; u[ltimos] v[otos] 24 agosto 1641, Tahupec (Sinaloa), México.

1 Parece que hay otra edición de esta obra, con el título abreviado de Biografía del P. Bartolomé Castaño, México, 1708. (Citada en Diccionario Enciclopédico Espasa, 12, 218). 
Estaba en Madrid al ser admitido en la C[ompañía] [de] J[esús] por el procurador de México, a donde pasó poco después. Cursados los estudios usuales en el Colegio Máximo de México, inició su labor (1632) en las misiones de Sinaloa (que abarcaban este estado y el sur de Sonora), con Pedro Pantoja. A los dos años catequizaba los indios sisibotaris y sahuaripas; llegaron (1636) a Ures, sobre el río Sonora, y misionaron (1638) Rosario Necameri (Rayón) sobre el afluente del río San Miguel. Además de Ures, fundaron Concepción Babiacora, San Pedro Acontzi, Remedios Banamichi (o Banamitzi) y, más al norte, San Ignacio de Senoquipe. Según los cronistas de la época, las conversiones entre los sonoras fueron mucho más rápidas que entre otras naciones, ya que en solo un año entre ambos habían bautizado 2.819 adultos y 1.527 párvulos.

Tal progreso movió a los superiores a fundar la misión de Sonora, aunque ya Pedro Méndez había entrado en tierras de los sisibotaris en 1621, y Jerónimo de Figueroa en el sur de Sonora en 1633. Pero fue Castaño con sus esfuerzos quien erigió (24 de abril 1639) la parroquia de San Francisco Javier, a cuya jurisdicción se asignaron las partidas de comoritas, aibinos, batucos, ures y sonoras. Las demás misiones de Sonora, con centro en San Ignacio, comprendían los ríos Yaqui y Mayo, entre las naciones de los tepehuas, conicaris, o nabas y movas. El fruto fue tan copioso que a los siete años (1646) se necesitó hacer una nueva división según los cuatro ríos de la región: San Miguel, Moctezuma, Bavispe y Sonora.

Destinado a la casa profesa de México como operario (1648-1650), fue rector (1656-1658) del colegio de Oaxaca, de cuyo cargo pidió ser relevado para regresar a la casa profesa, donde permaneció los últimos trece años de su vida. Durante esos años, ganó fama de predicador; pero su principal labor fue la de misionero. Gran padre lengua, sus dotes lingüísticas quedaron demostradas con dominio de seis lenguas indias, en las que redactó varios catecismos, uno de ellos utilizado en México hasta mediados del siglo XX. Empleó la música como instrumento de evangelización entre esos pueblos amantes, como pocos, de la danza y el canto. Fue insigne el modo de compartir la vida cotidiana de sus pueblos norteños. El tono moreno de su rostro le hacía más cercano a sus sonoras y sahuaripas» ${ }^{2}$.

Son varios los extremos no aclarados como sería de desear en la nota transcrita. En primer lugar, que, castellanizado, su nombre portu-

2 F. Zubillaga - J. Gómez, Castaño, Bartolomé, en Diccionario Histórico de la Compañía de Jesús, 698-699. 
gués sería Bartholomé Castanho, aunque nunca se vea escrito así actualmente; ninguna información adicional sobre su familia, ocupación, procedencia anterior, etc. En segundo lugar, la nota señala con dudas que nació hacia 1601 («circa»), sin afirmarlo taxativamente; después, prácticamente todos los que han escrito sobre él han dado la cifra por totalmente cierta, sin resquicio para la fluctuación que aquí se indica. En tercer lugar, tampoco se aclaran los motivos de que estuviera en Madrid en 1622, cuando fue admitido en la Compañía de Jesús, por el provincial de México, que hay que suponer estuviera por esas fechas en España; Castaño contaba aproximadamente 21 años por entonces; habría hecho algunos estudios; $y$ los motivos de su traslado a Madrid quedan en la penumbra (¿familiares, económicos, religiosos,...?). Se entiende que, con un deseo sincero de contribuir a difundir el evangelio, se dirigiera al provincial mexicano, aunque es posible que fuera orientado en esa dirección por algún otro jesuita con quien entablara contacto.

La nota anterior, además, proporciona la información de que se trataba de una persona de tez morena, que más adelante, en México, le facilitó el contacto con los indios con los que trabajó, también de piel oscura. Disponemos de información de que llegó a dominar seis lenguas, pues cada acción misional en diversas localidades requería el conocimiento de una determinada. Muy cautamente, la información a propósito de las lenguas se limita a insinuar «que redactó varios catecismos»; no se precisa nada más, ni número exacto, ni título, ni lengua en que estuvieran redactados, pues todo está en el aire. La información adicional de que «uno de ellos [era] utilizado en México hasta mediados del siglo XX», apenas hace avanzar algo más, pues, de ser cierto que escribiera varios, tampoco se señala cuál tuvo una pervivencia. Todo ello deja las puertas abiertas, y nada compromete.

Sommervogel aporta la noticia del apelativo con que era conocido por los indios, como el «Indio sabio de la Sonora» ${ }^{3}$, pero Uriarte, quizá precipitado al escribirlo, lo alteró por el de «Indio sabio de sotana» 4 , que ciertamente no dice lo mismo; a este propósito, se percibe una notable exageración cuando se llega a afirmar que «los indígenas en muchas ocasiones le tomaron por un sabio de su raza» ${ }^{5}$; por muy moreno que fuera y por muy bien que hablara su lengua, la exageración resulta clamorosa. II, 823.

3 C. Sommervogel, Bibliothèque de la Compagnie de Jesus, Bruxelles/Paris, 1891,

4 J. E. DE URIARTE, Biblioteca de escritores de la Compañía de Jesús, Madrid, 19291930, II, 156-157.

${ }^{5}$ Diccionario Enciclopédico Espasa, 12, 218. 
Aún aparece otra exageración más en la entrada que le dedica José Rogelio Álvarez, cuando afirma que «hizo labor de catequista durante 25 años en Sinaloa y Sonora, utilizando la música para atraer a los indios» 6 , ya que si comenzó su actuación en 1636, y se retiró a la casa profesa de la ciudad de México en 1648, fueron tan sólo 12 años, aunque bien aprovechados, no 25, los que dedicó a esta tarea.

Aún he detectado otra inexactitud en torno a sus datos biográficos, pues, al hablar de su catecismo, J. Cortés duda de la paternidad de esta obra y dice:

«Más aún, tampoco se puede poner una fecha anterior al año 1641 [por errata: 1541], ya que consta que fue compuesto para sus destinatarios los "sahuaripas y sonoras". La razón es que hasta después de la profesión de cuatro votos, el 24 de agosto de 1641, y solamente después de esta "profesión" fue enviado como misionero primero a Sinaloa y luego a Sonora» 7 .

Ha aparecido que desde 1636, con cinco años de anterioridad a la emisión de sus últimos votos, estuvo dedicado a la misión entre estos pueblos, lo que invalida la afirmación de Cortés, que parecía tan firme, pues la emisión de sus últimos votos no interrumpe la actuación misional que estaba llevando desde tiempo atrás. En el relato biográfico de Zubillaga y López se hace referencia conjunta a Bartolomé Castaño y a su compañero Pedro Pantoja, quienes durante años compartieron las tareas misionales. También se nos informa que la labor evangelizadora había sido iniciada ya por otros misioneros jesuitas, lo que no quita mérito al esfuerzo llevado a cabo. Cuando el informe se centra en Castaño exclusivamente destaca sus cualidades, particularmente en el terreno de la música, en la redacción de escritos catequéticos, y en la organización eclesial de la misión.

Como se puede comprobar en las informaciones precedentes, son muchos flecos los que quedan sueltos; son varias las afirmaciones que se dan por válidas sin serlo; son algunas apreciaciones las que se suponen sin verdadero fundamento. Esto quiere decir que, según se consulte una fuente o varias, y se contrasten, se puede deducir una u otra verdad incompleta, o una exactitud que es preciso matizar.

6 J. R. Álvarez, Enciclopedia de México, México, 1987, III, 1406.

7 J. Contés, El catecismo pictográfico de Fr. Pedro de Gante, Madrid, Fundación Universitaria Española, 1987, 268. 


\section{El Catecismo breve}

Si lo consignado hasta aquí tiene unas apoyaturas firmes, junto a algunas lagunas, el paso siguiente, al hablar del Catecismo que se le atribuye, nos hace penetrar en un terreno movedizo en el que nada o casi nada se puede dar por seguro.

Ya he señalado que la nota biográfica en que sustancialmente me apoyo opta por la cautela cuando asegura con frase genérica «que redactó varios catecismos; uno de ellos utilizado en México hasta mediados del siglo XX». De manera difusa se quiere dejar a salvo la información tradicional que asigna a Castaño un catecismo breve, un resumen apretado de la fe cristiana, puesto a su nombre y del cual se han efectuado numerosísimas ediciones. Sin embargo, resulta muy mal conocido.

En aras de la verdad, es preciso comenzar por dejar clara una seria duda con fundamento bastante sólido acerca de que escribiera ese catecismo. De hecho, Tomás de Escalante escribió la obra que he anotado (Breve noticia de la Vida exemplar y Dichosa muerte...) a partir de la información recogida de primera mano de Francisco Ximénez, prepósito de la Casa profesa de México, en la que Castaño falleció el 16 de diciembre de 1672. Ximénez fue testigo de primera mano y redactor primero de una sucinta información que tan sólo siete años después, en 1679, completó y a la que dio forma Tomás Escalante; éste tampoco estaba excesivamente distante de los hechos, y manejó información fiable. Pues bien, al momento de su muerte, al dejar constancia de sus pertenencias y escritos:

«habla de dos de sus escritos: Un tratado de la virtud de la charidad, y Tratado del acto de contrición, incluso de dos quadernos de oratoria que se encontraron entre sus cosas después de que murió, y no hace ni siquiera la más mínima alusión del mencionado y tan utilizado Catecismo» 8 .

El punto de partida es, por consiguiente, negativo: Castaño no escribió catecismo alguno, o no se hace alusión ni de uno que hubiera resultado más difundido y célebre, ni menos aún de varios que hubiera redactado. Si Bartolomé Castaño permaneció en la casa profesa de México los

8 J. CORTÉs, o. c., 268, quien remite a la obra de Tomás de Escalante, de 1679, f. 2 r. Sommervogel, o. c., 824, además del catecismo, deja constancia de cuatro obras: «Tratados de la virtud de la Caridad y de la Contrición (dos escritos, agrupados en un sólo título); Método de usar y venerar las Imágenes, y Tres libros de Cartas espirituales, que existen en el Monasterio de Religiosas de la Encarnación de Mégico». 
últimos trece años de su vida, y en ella residía también como prepósito Francisco Ximénez, es muy poco verosímil que en tan dilatado espacio de tiempo no hubiera salido alguna noticia, información o comentario sobre esos catecismos. Hay que partir, por tanto, del hecho de que Castaño no escribió varios catecismos, ni tan siquiera uno.

Por tanto hay que trabajar en la dirección de tratar de averiguar por qué razón a un catecismo breve, del que de momento es preferible no hablar de ningún autor, se le asignó el nombre de Bartolomé Castaño. Pero esto es asunto bien distinto de afirmar sin dudas que escribió uno.

Sin embargo, las informaciones o las referencias bibliográficas consultadas proceden de esta forma y no dejan la más mínima duda acerca de la autoría como si se tratara de un hecho comprobado que escribió un catecismo. Es uno de tantos casos en que, a fuerza de repetir lo que otros han escrito se termina por asegurar lo que no es seguro. Es lo que sucedió con el mismo Castaño, pues aunque una información no asegure más que aproximadamente la fecha de su nacimiento, se pasa de ahí a afirmarlo con total firmeza y aplomo.

Las referencias a su Catecismo, abreviadas y ordenadas cronológicamente son:

- Sommervogel (1891), II, 823, le señala como autor de Catecismo breve...9.

- José Ma Solá (1907) enfatiza: «¿Cómo no hablar de... Castaño en nueva España?»10.

- Streit (1924) II, 602-603: le señala como autor del Catecismo breve, edición de 174411.

- Uriarte (1929), II, 156-157: constata ediciones desde 181712.

- Diccionario Enciclopédico Espasa, 12, 218: le señala como autor de un Catecismo, reimpreso en 1744, en español y en náhuatl.

- José Toribio Medina (1965), III, 306: habla del catecismo de Castaño, traducido al tarasco's

- José Rogelio Álvarez (1987), 1406: lo asegura para la edición de 1644 y sus traducciones ${ }^{14}$.

\footnotetext{
${ }^{9}$ SOMMERVOGEL, $o . c$.

10 J. Ma. SolÁ, El catecismo único en España, en "Razón y Fe" 17 (1907) 205.

11 R. STREIT, Bibliotheca Missionum, Aachen, Xaverius Verlag, 1924, II, 602-603.

12 URIARTE, $o . c$.

13 J. T. MedinA, La imprenta en México. 1539-1821, Amsterdam, 1956, III, 306: se refiere a la traducción de Ángel Serra que aparecerá más adelante.

14 Álvarez, $O . C$.
} 
La lista es elocuente: la repetición suministra certeza y parece despejar todas las dudas, incluso la duda inicial de que no se hace alusión a nada semejante a la hora de inventariar sus papeles y escritos. Es un claro ejemplo de construcción sin cimientos, que no resulta tan firme como se creía.

Hay que echar mano, inevitablemente de las ediciones conocidas, particularmente las más antiguas, para poder desenredar la madeja. Y esto entraña otro problema no despreciable, triple, tanto por los títulos con que se cita, por las fechas de edición, así como por las enormes lagunas que existen entre unas y otras ediciones.

\section{Los títulos}

Refiriéndose a la misma obra, la que se ha asignado a Castaño, hay una variedad de títulos que contribuyen a la desorientación, pues no siempre se adivina que el texto es el mismo.

Es preciso comenzar por el título que resulta más repetido, más habitual, más tradicional también, y que ha contribuido a consolidar a Bartolomé Castaño como autor: Catecismo breve de lo que precisamente debe saber el cristiano, sacado a luz por el R. P. Bartolomé Castaño, de la Compañía de Jesús.

Además de este título común, Cortés ${ }^{15}$ ofrece bien consignados los siguientes títulos variados:

- El Cathecismo en lengua Macahua y en lengua castellana por preguntas y respuestas ${ }^{16}$.

- Cathecismo en Lengua Mexicana ${ }^{17}$.

- Doctrina Pequeña dispuesto por el P. Bartholome Castaño de la Compañía de Jesús ${ }^{18}$.

15 J. CORTÉS, o. c., 268 y 427.

16 D. De Naguera (sic) Yanguas, Doctrina y enseñanza de la Lengua Mazahua. (Edición facsimilar de la de 1637, preparado con una nota introductoria de Mario Colín), México, Biblioteca Enciclopédica del Estado de México, 1970, 81-83.

17 En M. PÉREZ, Doctrina christiana y Cathecismo en Lengua Mexicana. Compuesto po0r el P. Alonso de Molina... Corregido ahora nuevamente por el R. Padre Lector Fr. _, México, Francisco Rivera de Calderón, 1718, 3-7.

18 En I. DE PAREDES, Catecismo mexicano. Dispúsolo primeramente en castellano el Padre Geronymo de Ripalda; lo traduxo del Castellano en idioma Mexicano el Padre Ignacio de Paredes de la misma Compañía de Jesús, México, Imprenta de la Biblioteca Mexicana, 1758, 143-150. 
- Doctrina Christiana fielmente traducida de la que escribió el R. P. Bartholomé Castaño de la Compañía de Jesús, por ser la que la experiencia ha mostrado más acomodada para gente rústica ${ }^{19}$.

A estas cuatro referencias hay que añadir aún otras dos más, que son dos estudios sobre un mismo texto pictográfico, pero cuyo equivalente es el catecismo asignado a Castaño:

- A Mazahua Catechism in Testera-Amerind Hierogliphics ${ }^{20}$.

- Un Catecismo Mazahua (En jeroglífico Testeramerindiano)21.

La diversidad de títulos no contribuye más que a despistar, porque, como es posible apreciar, tan sólo en dos de los reproducidos aparece el nombre de Bartolomé Castaño, mientras que en el resto no consta, lo que conduce a la dispersión de esfuerzos.

\section{Las fechas y los intervalos}

Seguiré, como es natural el orden cronológico, indicando las fuentes de las ediciones que se citan en cada caso. A la vez aparecen las lagunas que existen entre unas y otras fechas, lo que proporciona una visión conjunta de lo poco que se sabe y lo mucho que se desconoce de este Catecismo.

1. 1637: La referencia más antigua es la de 1637, en la edición de la obra de Diego de Nájera ${ }^{22}$ titulada Doctrina y enseñanza de la lengua mazahua, 1637; de ella se ha hecho una edición facsímil, en que el apellido aparece escrito como «Naguera» 23 , hay que advertir que esta obra se publicó aún en vida y plena actividad de Castaño entre los indios.

19 En C. Tapia Zenteno, Noticia de la Lengua Huasteca... con Cathecismo y Doctrina Christiana según lo que ordena el Santo Concilio Mexicano, México, Imprenta de la Biblioteca Mexicana, 1767, 96-99.

20 N. LEON, A Mazahua Catechism in Testera-Amerind Hierogliphics, en "American Anthropologist”. New Series, New York, 1900, v. II, 726ss.

21 M. COLIN, Un Catecismo Mazahua (En jeroglífico Testeramerindiano), México (=Biblioteca Enciclopédica del Estado, nº 13), 1968.

22 Ver nota 16. Diego de Nájera, religioso, nacido en 1570 y muerto en 1635 . Fue cura y párroco de Xocotitlán (México). Destaca por ser el primero en escribir una obra en mazahua (Doctrina y enseñanza de la lengua mazahua, 1637). Ver: http://www.monbiografias.com

${ }^{23}$ Ver nota 10. 
2. 1644: Más adelante, aparece otra referencia a una edición de 1644, también en vida de Castaño; está recogida en la entrada de José Rogelio Álvarez, sobre Castaño, sin más apoyatura que afirmarlo: «Su catecismo (1644) fue traducido al náhuatl, al tarasco y al otomí». (¿Podría tratarse de una simple errata?: 1644 por 1744?).

3. 1718: Es la edición de Manuel Pérez, ya vista al hablar de los variados títulos, traducida al náhuatl por el agustino cuyo nombre figura en portada ${ }^{24}$.

4. 1731: El informante es en esta ocasión José Toribio Medina, cuando consigna una obra de Ángel Serra, titulada Manual de administración de sacramentos..., México, Joseph Bernardo de Hogal, 1731. Indica que esta obra está anunciada en el no 39 de la "Gazeta de México", febrero de 1731, y al describirla incluye: «... instrucción de la Santa Fe, según el Catecismo del P. Bartolomé Castaño, de la Compañía de Jesús, todo en dicha lengua tarasca» 25 .

5. 1744: El paso siguiente aparece en una edición más documentada, realizada en México, Vda. de Joseph Bernardo de Hogal, 1744: así lo hacen constar Sommervogel, Streit, y el Diccionario Enciclopédico Espa$s a$. Sommervogel añade a propósito de esta edición: «Grande feuille pliée, imprimé d'un seul coté». Por su parte, Streit adjunta otra información: «[mit spanischem und mexikanischem Text]».

6. 1758: Se trata del interrogatorio atribuido a Bartolomé Castaño, con el título que ya apareció al consignar los varios títulos Doctrina pequeña dispuesta por el P. Bartholomé Castaño de la Compañía de Jesús. Esta doctrina consta en Catecismo mexicano. Dispúsolo primeramente en Castellano el Padre Geronymo de Ripalda... lo traduxo del Castellano.. en Idioma Mexicano el Padre Ignacio de Paredes de la misma Compañía de Jesús, México, Imprenta de la Biblioteca Mexicana, 1758; es edición náhuat ${ }^{26}$.

24 Ver nota 17. Es preciso destacar que el título de la traducción de Manuel Pérez asigna la obra, sin dudas, a Alonso de Molina.

25 J. Toribio Medina, La imprenta en México, IV, 325-326.

26 A esta edición se refiere A. MÉndez Plancarte, Dos textos catequísticos: el Ripalda frente al Gasparri, México, 1951, 157, nota 12: «Esta cartilla del P. Castaño, "que usaba en sus misiones de sahuaripas y sonoras" hacia 1644 (G. Decorme, La obra de los 
7. 1758: La transmite José $\mathrm{M}^{\mathrm{a}}$ Solá, como «Catecismo mexicano, México, 1758»27; remite a Nicolás Antonio como fuente, pero no he dado con la referencia de este bibliógrafo.

8. 1767: Figura en la edición de Tapia Zenteno, que incluye una información sobre la lengua huasteca, y un catecismo adjunto: Noticia de la Lengua Huasteca... con Cathecismo y Doctrina Christiana según lo que ordena el Santo Concilio Mexicano, México, Imprenta de la Biblioteca Mexicana, 1767, 96-9928.

9. 1778: El informante también es José Toribio Medina, al hablar de una obra anónima titulada Actos de Fe, Esperanza y Caridad, que todo fiel christiano está obligado a hacer con frequencia y devoción, especialmente a la hora de la muerte y a confesar los principales misterios de nuestra Santa Fe, que se contienen en la siguiente..., Reimpreso en la Imprenta de la Biblioteca Mexicana, 1778, que anota: «Contiene "Catecismo breve de lo que precisamente ha de saber el cristiano. Sacado a luz por el R. P. Bartolomé Castaño, de la Compañía de Jesús"»29. No es raro, como aparecerá más adelante, dada además la brevedad del texto que se atribuye a Castaño, que aparezca adjunto a otras obras de corte catequético.

10. 1803: En edición reimpresa, consignada a la imprenta de Puebla, Pedro de la Rosa, 1803. La edición aparece registrada por Sommervogel y Streit.

11.1817: Se trata de una edición hecha en México, en la que no consta el nombre del impresor, sino la dirección en que estaba ubicado su taller: México, Calle del Espíritu Santo, 1817. La recogen los mismos Sommervogel y Streit, y además Uriarte. La breve descripción señala que es edición bilingüe (mexicano, no especificado, es decir, se supone que náhuatl, y español), y que incluye además el acto de contrición y el credo.

12. 1836: Esta edición se llevó a cabo en Puebla, en la imprenta del Hospital de San Pedro. Informan de ella Sommervogel y Streit; la edición

\footnotetext{
jesuitas mejicanos, t. I, p. 275, nota), se incorpora al final del Ripalda en la edición náhuatl del P. Paredes (Méjico, 1758), o acaso ya antes».

27 José Ma SolÁ, El catecismo único en España, en “Razón y Fe” 17 (1907) 205.

28 Nota 19.

29 J. Toribio Medina, La imprenta en México, V, 255-256.
} 
tiene la particularidad de una errata en el apellido, que figura como «Cataño».

13. 1856: También es edición de Puebla, por el impresor A. Castillero, 1856. La información aparece también en Sommervogel y Streit. Es edición dependiente de la anterior, ya que repite la errata de «Cataño», fallo que sólo indica Streit.

14. 1859: Consta en Sommervogel la noticia de un catecismo de Ripalda que incluye además el Catecismo breve de Castaño, en una edición de México, en la que no consta la imprenta, aunque sí la fecha.

15. 1871: Está adjunta la obra de Castaño a una edición de Ripalda hecha en México, Imprenta de Murguía, 1781, que tengo a la vista; el escrito de Castaño ocupa las p. 150-152.

16. Sin año: Tanto Sommervogel como Streit consignan una edición de lo que parece, por el título, únicamente el escrito atribuido a Castaño, en edición que carece de pie de imprenta, sin lugar, sin impresor, y sin año. De esta edición, y de la siguiente, Sommervogel indica: «Ces deux éditions diffèrentes, du XIX siècle, me viennent du Mexique».

17. Sin año: Además hay constancia de una edición, o manuscrito, que se titula: Methodo breve para confesar a un Indio, en Idioma Othomí, que añade el texto de Bartolomé Castaño; Sommervogel informa de este escrito. Streit da información de un Catecismo y breve explicación de la Doctrina en Idioma Othomí. Lo que precisamente debe saber el Christiano; afirma que es manuscrito, aunque no indica, como hace Sommervogel, que está adjunta al método para la confesión. Podría tratarse de información coincidente, y estaríamos hablando de un ejemplar; o divergente, y serían dos ejemplares en ese caso.

La secuencia cronológica es irregular, con grandes saltos, con escasas constataciones intermedias entre ejemplares conocidos, y con el convencimiento de los muchos ejemplares que existieron, que cubrirían en gran medida esas lagunas, y que hoy no se encuentran o no resulta fácil dar con ellos.

La cadencia cronológica examinada es: 1637 - ¿1644? - 1718 - 1731 1744 - 1758 - 1758 - 1767 - 1778 - 1803 - 1817 - 1836 - 1856 - 1859 - 1871 - s. a. - s. a. 
A esto habría que añadir la información que prolonga esa secuencia, cuando asegura que hasta mediados del siglo XX se ha seguido repitiendo y utilizando ${ }^{30}$. No se trata de reconstruir la historia de este breve texto, sino de ver que ha perdurado en el tiempo, por encima de otras consideraciones, acaso porque, dada su brevedad, simplicidad y poco precio, podía estar fácilmente al alcance de muchas más personas que las que tenían que hacer un mayor esfuerzo económico para adquirir el texto del que se denominaba como catecismo de Ripalda; y además se veían obligados a un mayor esfuerzo intelectual para conocerlo y aprenderlo. Ambos textos -Castaño y Ripalda- han convivido uno junto al otro, a lo largo del tiempo, aunque no siempre ha sido así. Y en más de un caso se ha empezado por la simplicidad del escrito que se asignaba a Castaño, para, una vez conocido y aprendido, dar el salto al más extenso texto de Ripalda.

\section{¿Quién fue el autor?}

Estos retazos históricos permiten una cierta visión panorámica de la vigencia que tuvo el texto de Castaño. Pero subsiste una pregunta fundamental: ¿cuál fue su origen?, ¿quién fue su autor? $\mathrm{Si}$, a lo que parece, Castaño no lo escribió, pues nada alude a él entre sus papeles personales, es preciso indagar otro origen.

La fecha de 1637 -en vida de Bartolomé Castaño- cuando llevaba cinco años misionando en Sinaloa, remite a la edición de la obra de Diego de Nájera, Doctrina y enseñanza de la Lengua Mazahua, ya mencionada. En ella se encuentra un ejemplar de este Catecismo breve; el que se encuentre allí no quiere decir que todo cuanto forma parte del libro sea obra de Diego de Nájera. Es evidente que éste pudo servirse de cosas escritas por otro autor, fuera de Bartolomé Castaño, o procediera de otro escritor. Ese Catecismo breve, que ciertamente lo es, pudo ser empleado por Nájera de la misma forma que pudo ser utilizado por Castaño: nadie se lo impedía a ninguno de los dos.

Es preciso, pues, remontarse aún más, desandar un camino cada vez más incierto, por falta de datos, para rastrear alguna luz. En su obra de desciframiento y traducción del catecismo pictográfico que se atribuía a

30 Así, J. Cortés, o. c., 428, nota 119: «Tenemos a la vista ediciones recientes del Catecismo de Ripalda acompañado, casi como de un apéndice, del de Castaño: 1934, 1935 y 1956; estas tres ediciones constan del mismo número de preguntas y respuestas: $24 »$. 
Pedro de Gante, Justino Cortés sigue un procedimiento con el que manifesté mi desacuerdo, pues entre otros recursos busca paralelismo entre el lenguaje pictográfico, a base de glifos, dibujos, con los que se llegó a expresar la fe cristiana, y el lenguaje hablado o escrito, que tiene otras posibilidades, otros recursos propios, que emplea con mayor frecuencia palabras más abstractas, y que dispone de una sintaxis radicalmente diferente de la que se puede encontrar en el lenguaje pictográfico.

A la hora de emprender la traducción de la parte séptima del catecismo pictográfico que se atribuye a Pedro de Gante, que consta de preguntas y respuestas, Cortés, examina la información disponible y llega a la siguiente conclusión:

«La búsqueda de su solución nos condujo a indagar alguna fuente anterior a la publicación de este texto catequístico [se refiere al de Diego de Nájera] y posterior a la segunda edición de la Doctrina christiana... de fray Pedro de Gante. Consideramos haberla encontrado, pero no en las doctrinas "largas" de Molina y de los Dominicos, sino en la del mismo fray Pedro de Gante, como se verá un poco más adelante, aunque debe reconocerse que varias respuestas son mucho más amplias y, algunas, se hallan en lugares distintos, que oportunamente indicaremos» 31 .

La pista señalada por Cortés no es mala, sino todo lo contrario. Dicha pista le llevó a buscar el desciframiento del texto pictográfico, y, según sus mismas palabras, recopiló la información que le facilitara ese desciframiento en diversos lugares de la Doctrina christiana... -texto impreso, no pictográfico- de Pedro de Gante.

Ahora bien, hace años emprendí otro desciframiento del catecismo pictográfico que se atribuía a Pedro de Gante ${ }^{32}$, -yo afirmo que sólo una parte es de Pedro de Gante, el denominado Catecismo incompleto-. Sin necesidad de incorporar semejanzas precedentes de la Doctrina christia$n a$, de Pedro de Gante, como hace J. Cortés, para esta sección de preguntas y respuestas, descifré lo que los pictogramas expresan por sí mismos, desde la lógica interna del lenguaje pictográfico.

El resultado a que llegué muestra un texto bastante sorprendente, breve, en preguntas y respuestas, tal como está redactado, que se atiene sólo a algunos aspectos de la fe cristiana, los fundamentales, en síntesis

31 J. CORTÉs, El catecismo en pictogramas de fray Pedro de Gante, Madrid, Fundación Universitaria Española, 1987, 267 y 269.

${ }^{32}$ L. Resines, Catecismos pictográficos de Pedro de Gante, Incompleto y Mucagua, Madrid, Fundación Universitaria Española, 2007. 
apretada con claras referencias al credo y una breve alusión final sobre la eucaristía, la penitencia y la salvación.

Es imposible desconocer las similitudes que esta sección de preguntas y respuestas tiene con la que se denominó como Catecismo breve asignado a Castaño; también aparecen unas divergencias que no hay forma de ocultar. Pero pesa más, sin duda, el conjunto de las semejanzas que el de las diferencias. ¿Puede ser éste el origen de las preguntas y respuestas que se pusieron dos siglos después a nombre de Bartolomé Castaño?

Antes de presentarlo, es imprescindible una advertencia: el catecismo pictográfico que se atribuía a Pedro de Gante tiene un paralelo en el catecismo pictográfico mucagua, que sigue muy de cerca a aquél, aunque no siempre son idénticos. Por ello, he preferido presentar a cuatro columnas el texto del pictográfico con el nombre de Gante, del pictográfico mucagua, del pictográfico acompañado de texto náhuatl y del asignado a Bartolomé Castaño; de esta forma es más fácil llevar a cabo un cotejo más exhaustivo.

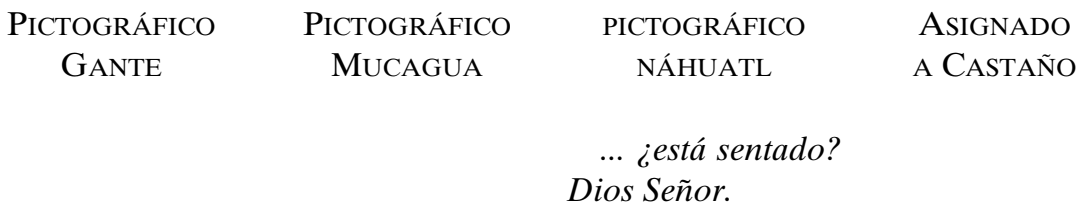

1. ¿Cuántas divi- $\quad$ 1. ¿Cuántas divi- $\quad$ 1. ¿Cuantos dio- 1. Decid, hermanidades [hay]? nidades [hay]? ses [hay]? [Uno]. no, ¿cuántos DioUna divinidad, Una divinidad, ses hay? Un solo Dios. Dios. Dios verdadero.

2. ¿Dónde [está] 2. ¿Dónde [está] 2. ¿Dónde está 2. ¿Dónde está la divinidad, Dios? la divinidad, Dios? el] Dios Señor? Dios? En el cielo, Este está [en el] Éste está [en el] Está sentado en el en la tierra y en cielo y [la] tierra, cielo y [la] tierra, cielo y [en la tie- todo lugar.

[en] todo [lugar] [en] todo [lugar] rra].

está. está. 
3. ¿Quién hizo 3. ¿Quién hizo 3. ¿¿Quién hizo 3. ¿Quién hizo [el] cielo y [la] tie- [el] cielo y [la] tie- todo?] [Dios es] el cielo, y la tierra rra? [La] santa rra? [La] santa hacedor del cielo y y todas las cosas? divinidad, Dios. divinidad, Dios. tierrar Dios nuestro

Señor.

4. ¿Quién es la 4. ¿Quién es la 4. ¿La santa 4. ¿Quién es divinidad, Dios? divinidad, Dios? divinidad [es Dios? La SantísiEs esta venerada Es esta venerada Dios]? [La santa ma Trinidad. Trinidad. Trinidad. divinidad es Dios].

5. ¿Quién [es] la 5. ¿Quién [es] la 5. [Quién es] la 5. ¿Quién es la santa, venerada, santa, venerada, santa, muy santa Santísima TriniTrinidad? [Es] este Trinidad? [Es] este Trinidad? La dad? Dios Padre, Dios Padre, Dios Dios Padre, Dios santa, muy santa Dios Hijo y Dios Hijo, Dios Espíritu Hijo, Dios Espíritu Trinidad [es Dios Espíritu Santo, Santo, tres perso- Santo, tres perso- Padre, Dios Hijo, tres personas disnas, una divinidad, nas, una divinidad, Dios] Espíritu tintas y un solo Dios.

Dios.

Santo, tres divini- Dios verdadero.

dades, tres perso-

nas [y un solo

Dios].

6. ¿[Es] este 6. ¿[Es] este 6. ¿[Este Padre] 6. ¿El Padre es Dios Padre divino? Dios Padre divino? es Dios? Sí. Dios? Sí.

Sí. Sí.

7. ¿[Es] este 7. ¿[Es] este 7. ¿Este Hijo [es 7. ¿El Hijo es Dios Hijo divino? Dios Hijo divino? Dios?] Sí. Dios? Sí.

Sí.

Sí.

8. ¿[Es] este 8. ¿[Es] este 8. ¿[Este] Espíri- 8. ¿El Espíritu Dios Espíritu Dios Espíritu tu Santo es Dios? Santo es Dios? Sí. Santo divino? Sí. Santo divino? Sí. Sí.

9. ¿Cuántas 9. ¿Cuántas 9. ¿Son tres dio- 9. ¿Son tres Dio[hay], tres divini- [hay], tres divini- ses? No, uno creo ses? No, sino un dades? No, una dades? No, una Dios Señor. solo Dios verdadedivinidad, Dios, divinidad, Dios, ro, que aunque en [en] tres personas. [en] tres personas. Dios hay tres personas, todas son un 
mismo Dios, porque tienen un mismo ser y naturaleza divina.

10. ¿Quién se 10. ¿Quién se 10. ¿Qué perso- 10. ¿Cuál de las hizo hombre? [La] hizo hombre? [La] na [se hizo] hom- tres personas se segunda persona, segunda persona, bre divino? Esta hizo hombre? La [el] Hijo Dios, [el] Hijo Señor segunda persona segunda, que es el Dios Jesucristo. Jesucristo. llegó a ser, [el] Hijo, al cual, desHijo Dios, Señor pués de haberse Jesucristo. hecho hombre, llamamos Jesucristo.

11. ¿Quién [es 11. ¿Quién [es 11. ¿Quién [es 11. ¿Quién es el] Señor Jesucris- el] Señor Jesucris- el] Señor Jesucris- Jesucristo? Es verto? Este creo [que to? Éste creo [que to? Éste creo Dios dadero Dios y veres] divinidad; creo es] divinidad; creo y creo hombre. dadero hombre. [que es] hombre, [que es] hombre, verdadero hombre verdadero hombre [el] Señor Jesucris- [el] Señor Jesucristo. to.

12. ¿Quién nació 12. ¿Quién nació 12. ¿Cómo se 12. ¿Dónde se de María? [La] de María? [La] hizo hombre ver- hizo hombre? En poderosa María poderosa María dadero [el] Señor el vientre virginal [es] santa por el [es] santa por el Jesucristo? Éste de la Virgen Santa Espíritu Santo, Espíritu Santo, estuvo en el vientre María por obra del madre [del] hom- madre [del] hom- [de] María, [que] Espíritu Santo, bre. bre. siempre creo vir-quedando ella gen, por obra, por siempre Virgen y orden [del] Espíri- verdadera Madre tu Santo. de Dios.

13. ¿[Por]quése 13. ¿[Por] qué él 13. ¿Y quién [es] 13. ¿Por qué se hizo hombre [el] mandó [como] la siempre virgen hizo hombre el Señor Jesucristo? hombre [al] Señor madre María? Hijo de Dios? Para [A] nosotros peca- Jesucristo? [Para] Santa María llegó a salvar a nosotros dores [de] los nosotros pecadores ser madre, siempre pecadores.

pecados librarnos. [de] los pecados virgen y llena [de] librarnos.

toda abundancia

[de] gracia $y$

dones; Dios en su 
interior está; pero creció, nació el dueño [del] cielo y tierra; es madre siempre.

14. ¿Y dónde está, dónde [la] madre, siempre virgen María? En el cielo permanece [con] cuerpo y alma, [en] premio fue subida, y todos a la divinidad, Dios; pero(?) pedimos [por] María a la Trinidad.

15. ¿Y por qué fue hombre verdadero el Señor Jesucristo? Para [a] los malos pecadores [de] éstos [pecados] librar.

14. ¿Qué hizo 14. ¿Qué hizo 16. ¿Qué hizo el 14. ¿Qué hizo [el] Señor Jesucris- [el] Señor Jesucris- señor Jesucristo Cristo en la tierra to cuando [estuvo] to cuando [estuvo] [al] vivir [en la] para salvarnos? [en la] tierra? [en la] tierra? tierra a librarnos? Padeció debajo del Librarnos [del] el Librar a nosotros Éste castigo sufrió poder de Poncio castigo, padeció [del] castigo, pade- por orden [de] Pilato, fue crucifipor orden [de] ció por orden [de] Poncio Pilato, fue cado, muerto y Poncio Pilato; cru- Poncio Pilato; con- crucificado en la sepultado, descencificado [del] todo denado, crucifica- cruz, muerto, dió a los infiernos, [en la] cruz; muer- do [del] todo [en sepultado; descen- resucitó, subió a to y sepultado; bajó la] cruz; muerto y dió al infierno; [al] los cielos y está [al] infierno; [al] sepultado; bajó [al] tercer día resucitó sentado a la diestercer día resucitó, infierno; [al] tercer de entre los muer- tra de Dios Padre 
salió de entre [los] día resucitó, salió tos; subió al cielo; Todopoderoso, y muertos; subió al de entre [los] allá está sentado [a desde allí ha de cielo, a la derecha muertos; subió al la] derecha del venir a juzgar a los está sentado [del] cielo, está sentado Padre Señor; y de vivos y a los muerPadre Dios todo a la derecha [del] donde vendrá [a] tos.

poderoso; descen- Padre Dios todo juzgar [a] los vivos derá [a] juzgar poderoso; descen- y los muertos.

vivos y muertos. derá [a] juzgar

vivos y muertos.

15. Al morir 15. Al morir 17. El señor 15. Cuando [del] todo [en la] [del] todo [en la] Jesucristo, ¿fue murió Cristo en la cruz [el] Señor cruz [el] Señor muerto [como] cruz, ¿murió en Jesucristo, ¿murió Jesucristo, ¿murió divinidad, o cuanto Dios o en [como] divinidad y [como] divinidad y [como] hombre? cuanto hombre? [como] hombre? [como] hombre? No murió [como] No murió en cuanNo murió [como] No murió [como] divinidad, sino to Dios, sino en divinidad; sino divinidad; sino [como] hombre. cuanto hombre. [como] hombre [como] hombre murió. murió.

18. Y después 16. Y el hombre, [de] muertos [en] cuando muere, la tierra nosotros, ¿muere en cuanto ¿[qué] se hace, al alma? No muere muere el alma y en cuanto al alma, muere el cuerpo? sino en cuanto al No muere el alma, cuerpo.

sino el cuerpo

muere.

19. ¿Y qué?, 17. ¿Y el cuerpo ¿[para] siempre del hombre muere muere [el] cuerpo? para siempre? No, No, pues por obra porque el día del (¿orden?), después juicio se tornarán a de acabar [la] vida, juntar las almas donde [están] [los] con sus propios cadáveres, el cuer- cuerpos, y así resupo y el alma se reu- citarán para nunca nirán, y siempre más morir. 
[con] verdadera

alma.

16. ¿[Las] obras 16. ¿[Las] obras 20. ¿Y dónde 18. Dónde van [del] cristiano lle- [del] cristiano lle- irán los cristianos las almas de los van [a la] muerte, van [a la] muerte, después de muer-buenos cuando [o] llevan [al] [o] llevan [al] tos? Éstos al cielo, mueren sus cuercielo? Quien estos cielo? Quien estos pues cumplieron pos? Al cielo, a mandamientos des- mandamientos des- los mandamientos gozar de Dios para precia, [los] man- precia, [los] man- [que] el Señor siempre, porque damientos de la damientos de la Diosmanda. guardaron sus sandivinidad, [del] única divinidad, tos mandamientos.

Señor Dios verda- [del] Señor Dios, 21. ¿Y los malos, dero, al mal cristia- al mal cristiano lle- pecadores, éstos no llevan [a la] van [a la] muerte, caerán, donde [el] 19. ¿Y las de los muerte, llevan [al] llevan [al] infierno. infierno, pues no que mueren en infierno. Los que Los que cumplen cumplieron los pecado, dónde cumplen los man- los mandamientos mandamientos van? Al infierno, a damientos [de la] [de la] única divi- [que] el Señor padecer para siemdivinidad [que el] nidad [que el] Dios manda, y [los pre porque no Señor Dios orde-Señor Dios orde- de] la santa Iglesia. guardaron los na... [llevan al na... [llevan al mandamientos de cielo]. cielo]. Dios nuestro Señor y los de la santa Iglesia.

17. ¿[La] Iglesia 17. ¿[La] Iglesia 22. ¿Qué es la 20. ¿Quién es la Católica invisible Católica invisible santa Iglesia católi- santa Iglesia? La ordena [la] unión ordena [la] unión ca romana? Es la congregación de [de] todos [los] [de] todos [los] unión de los bauti- los fieles cristiahombres [que] cristianos [que] zados cristianos; nos, los cuales se rezan [al] Señor rezan [al] Señor [su] cabeza invisi- salvan muriendo Jesucristo? [A] Jesucristo? [A] ble el señor Jesu- en gracia. todos libra [de la] todos libra [de la] cristo, y viven en la muerte, lleva a la muerte, lleva a la tierra; miran [al] vida, perdona invi- vida, perdona invi- único visible, muy siblemente. siblemente. santo padre, [que] es el padre único [en la] ciudad [de] Roma. 


\begin{abstract}
23. Y los ángeles santos? Éstos son almas verdaderas, premiadas [por] el Espíritu Santo, los cuales siempre premiados, honran [y] alaban al Dios Señor donde [está en] el cielo.
\end{abstract}

24. ¿Cómo salvan [nuestras] obras? No, y [a] los cristianos todos juzgará a los hombres [por] las faltas [a] los mandamientos; los méritos santos donde ordena el señor [Jesucristo].

25. ¿...? y cuando... (...) ...los condenados al poder del infierno [y] del demonio.

18. ¿[Los] vene- 18. ¿[Los] vene- 26. Santo... (...) 21. ¿Quién está rados sacramentos rados sacramentos ...los sacramentos en el Santísimo [los] da el padre? [los] da el padre? salvan [por?] Dios Sacramento del [Los] sacerdotes, [El] sacerdote, [el] Señor... (...) ... el altar? Jesucristo, [el] padre [de la] padre [de la] misa, hombre [con] Dios nuestro Señor, vermisa, [con] poder [con] la invisible [en] el cielo. dadero Dios y ver[del] Señor Jesu- autoridad [del] dadero hombre.

cristo, [a quien] Señor Jesucristo, [a

creo Dios, [a quien] creo Diviniquien] creo hom- dad, [a quien] creo bre. Amén Jesús. hombre. Amén Jesús. 


\author{
Llegar en ayunas y \\ confesados, si \\ tuviéremos algún \\ pecado mortal.
}

23. Y para confesarnos, ¿qué debemos hacer? Pensar primero nuestros pecados, confesar todos los mortales con arrepentimiento y propósito de la enmienda.

24. Y para salvarnos, ¿qué debemos hacer? Guardar los mandamientos de la Ley de Dios y los de la santa Iglesia y las obligaciones de nuestro estado.

Las preguntas $15^{\mathrm{a}}$ y $16^{\mathrm{a}}$ del Catecismo breve asignado a Castaño tiene su paralelo en el Pictográfico náhuatl; luego las finales, $22^{\mathrm{a}}, 23^{\mathrm{a}}$ y $24^{\mathrm{a}}$, del de Castaño son las que no tienen ningún precedente. Pero el resto, las otras 18 preguntas tienen una notable similitud en cuanto al fondo de la doctrina que proponen, así como en cuanto a la forma, su redacción con los tres catecismos pictográficos. Examinadas una a una, se aprecia una mayor carga teológica en la $9^{a}$ del texto de Castaño, que se expresa con mayor exactitud y precisión, con lenguaje más abstracto que el que permite el texto pictográfico. Algo similar sucede en la pregunta $12^{\mathrm{a}}$, también de Castaño.

La pregunta $16^{a}$ de los dos primeros catecismos pictográficos citados tiene redacción distinta, pero se encuentra bastante bien reflejada en el conjunto de las preguntas $18^{\mathrm{a}}$ y $19^{\mathrm{a}}$ de los textos Pictográfico náhuatl, y el de Castaño.

También es preciso caer en la cuenta de otra no despreciable semejanza global: el orden en que se desarrolla la doctrina, con las salvedades de los incisos que se añaden a uno u otro testimonios, es prácticamente el 
mismo, lo que habla con bastante claridad de un mismo punto de partida, aunque luego quedara alterado con variantes.

\section{Con el paso del tiempo}

A la vista de lo precedente, creo que se puede afirmar que el contenido del que casi siempre se ha denominado Catecismo breve y se ha puesto ( $¿$ a partir de qué momento?) bajo el nombre de Bartolomé Castaño, se encuentra ya sustancialmente en la sección de preguntas y respuestas incluidas en el catecismo pictográfico atribuido a Pedro de Gante, así como en su paralelo, el catecismo pictográfico mucagua, e igualmente en el pictográfico náhuatl.

Estos dos catecismos, el que se asignó a Gante y el mucagua, no resultan fáciles de datar, pero es posible situarlos hacia el segundo tercio del siglo XVI (de 1540 en adelante). No veo nada de singular que, si ya circulaban en copias pictográficas, se pasaran a hacer copias en lenguaje no pictográfico, tanto manuscritas como impresas, pues ya estaba disponible la imprenta en México. La subsistencia de esas copias, su transmisión, su repetición y multiplicación no ha dejado rastro que actualmente resulte conocido.

Cuando estudié el catecismo pictográfico náhuatl, sin haber recabado la información actual en torno al que se suponía catecismo de Castaño, escribí:

«no comparto en absoluto la razón de la posible identidad con el catecismo de Ripalda o de otros catecismos afines, porque lo que aparece en este catecismo pictográfico no tiene nada que ver directamente con él, sino con el catecismo denominado como de Bartolomé Castaño; este detalle se le ha pasado totalmente a León-Portilla. Por consiguiente no hay que buscar apoyaturas para la fecha en la similitud con Ripalda. El argumento de la grafía lleva a datar el manuscrito a caballo entre los siglos XVI y XVII. No es posible hacer más precisiones. No hay ningún otro dato que permita avanzar más en la cuestión. Y el cotejo con el catecismo de Bartolomé Castaño, con las matizaciones que precisaré más adelante, no altera esta fecha poco precisa de principios del XVII» ${ }^{33}$.

33 L. RESINES, Estudio sobre el catecismo pictográfico náhuatl, en "Estudio Agustiniano" 40 (2005) 449-529. 
Lo que afirmé entonces, para datar el pictográfico náhuatl a partir del de Bartolomé Castaño, y situarlo a principios del XVII, hoy carece de validez. Si hay que remontarse hasta los tiempos de Pedro de Gante, hacia mediados del XVI, la fecha del pictográfico náhuatl queda como incógnita, porque los argumentos de León-Portilla tampoco determinan nada.

Con el paso del tiempo no es nada raro que este Catecismo breve se siguiera replicando. Es perfectamente posible que alguna de esas copias llegara hasta Diego de Nájera, y que éste la incorporara a su libro. También se pudo trasvasar al lenguaje pictográfico, no por simple copia de los precedentes pictográficos, sino por creación de nuevos y diferentes pictogramas, que expresaban básicamente el mismo contenido de la fe. Esta copia pictográfica (el pictográfico náhuatl) podría ser anterior a Diego de Nájera, o posterior a él, sin poder precisar más.

Tampoco tendría nada de particular que Bartolomé Castaño se hubiera servido de alguna copia para su labor misional. En algún momento imposible de precisar-sospecho que después de la muerte de Castaño- alguien añadió el nombre de este misionero a la síntesis que procedía de antes de él y que tanto él como otros utilizaron. A ello pudo contribuir que, puesto que Castaño llegó a dominar seis idiomas indígenas, hiciera versiones de esta síntesis a todos o a alguno de ellos; y que se dijera, simplificando, que era lo que Castaño había elaborado, cuando simplemente lo habría traducido. Una conjunción así pudo tener éxito, se repitió, se consolidó y se dio por válida sin más discusión, y se aceptó como una verdad histórica segura, que nadie puso en tela de juicio y fue repetida y aceptada por todos. Tendríamos, pues, el célebre texto del Catecismo breve, reproducido por un mecanismo de pura repetición, aceptado como escrito autónomo.

Sommervogel incluye a propósito de la entrada sobre Castaño una breve y lúcida nota: «La première édition est de longtemps antérieure». No precisa más. Pero de la misma forma que rastreando hacia sus orígenes creo haber podido dar con la fuente de donde surge esta pequeña síntesis en forma de preguntas y respuestas, avanzando hacia nuestros días, he localizado y consignado una serie de ediciones, que en modo alguno pretende ser una serie completa. Carezco de datos para poder cotejar unas y otras, pero tengo la certeza de que, aun siendo un texto breve, se le han podido hacer modificaciones, cambios, retoques,... Es posible que el ejemplar que pudo utilizar el mismo Castaño en sus días 
no fuera en todo idéntico a los que se han editado tiempo después con su nombre.

Las modificaciones que se han efectuado sobre este texto, denominado como de Castaño, han sido múltiples. Casi siempre han ido por la vía de añadir alguna otra pregunta. De ahí que haya que ser cautos al cotejar el texto denominado como de Castaño con los que le precedieron, y de donde parece que hay que deducir con certeza que procede. Es precisamente en las diferencias con los catecismos de donde procede donde se aprecian fundamentalmente dos detalles: el primero, que el lenguaje escrito, no pictográfico, permite una precisión teológica mucho mayor; el segundo, que las adiciones, es decir, las preguntas que no tienen paralelismo con los catecismos pictográficos, han de ser puestas bajo sospecha como preguntas añadidas, $y$, si fuera posible, averiguar quién ha sido su autor.

Este catecismo ha pasado por tantas manos que es poco menos que imposible rastrear los cambios y asignar a cada uno nombre concreto; casi todas las modificaciones que se han hecho han quedado anónimas. Estas modificaciones van desde la incorporación de un título (que ha variado de unos a otros), hasta la adición de nuevas preguntas, la traducción a diversas lenguas, la fusión de dos preguntas en una,...

En el momento presente habría que saber mantener para esta síntesis apretada de la fe cristiana el título ancestral de Catecismo breve de lo que precisamente debe saber el cristiano. Hasta aquí sería el título más exacto. Después habría que adicionar, bien diferenciado tipográficamente, que «Se utilizó con la adición de: sacado a luz por el R. P. Bartolomé Castaño, de la Compañía de Jesús»:

Catecismo breve de lo que precisamente debe saber el cristiano.

«Se utilizó con la adición de:

sacado a luz por el R. P. Bartolomé Castaño,

de la Compañía de Jesús». 